\title{
Haematin-dependent Oxidative Phosphorylation in Streptococcus faecalis
}

\author{
By D. G. BRYAN-JONES AND R. WHITTENBURY \\ Department of General Microbiology, University of Edinburgh \\ (College of Agriculture), West Mains Road, Edinburgh, $\mathrm{EH}_{9}{ }_{3} \mathrm{JG}$
}

(Accepted for publication 19 June 1969)

\begin{abstract}
SUMMARY
Functional cytochrome(s) and an oxidative phosphorylation system were demonstrated in Streptococcus faecalis grown on media supplemented with haematin. The membrane fraction of cell-free extracts coupled the oxidation of reduced NAD to the formation of ATP from ADP and in organic phosphate. This reaction was sensitive to cyanide, azide and Antimycin A. A $b_{2}$ type cytochrome was detected in the membrane fraction with absorption maxima at $4 \mathrm{I} 2,425,529$ and $559 \mathrm{~nm}$.
\end{abstract}

\section{INTRODUCTION}

Lactic acid bacteria normally lack haematin enzymes in their election transport system (Dolin, 1953) but are able to grow aerobically with oxygen as a terminal electron acceptor (Whittenbury, 1964). Only in one instance has it been claimed that oxygen utilization is coupled to the synthesis of ATP; Gallin \& Vandemark (1964) showed oxidative phosphorylation with extracts of Streptococcus faecalis. As the organism lacked haematin enzymes Gallin \& Vandemark postulated that phosphorylation might occur at the 'DPNH/flavin' level or, alternatively, during the oxidation of napthoquinone, shown to be present in $S$. faecalis by Baum \& Dolin (I963). The possibility that some lactic acid bacteria might form functional cytochromes and have conventional oxidative phosphorylation arose from the observation of Whittenbury (1964) that many types of lactic acid bacteria synthesized catalase when provided with haematin and that a few strains also formed cytochromes of the $a$ and $b$ types. Of those strains possessing cytochromes, only $S$. faecalis seemed to benefit functionally in that colony size was markedly increased on media containing haematin, above colony size on media lacking haematin. Consequently an investigation has been made of $S$. faecalis growing on media supplemented with haematin. Evidence is presented for the presence of a cytochrome electron transport system in haematin-grown $S$. faecalis, resulting in oxidative phosphorylation coupled to the oxidation of reduced pyridine nucleotide.

\section{METHODS}

Organism. Streptococcus faecalis 58 I (National Collection of Dairy Organisms).

Basal medium. Basal medium contained $0.5 \%$ yeast extract, $0.5 \%$ peptone and $0.5 \%$ Lemco (all w/v) adjusted to $\mathrm{pH} 6.5$, sterilized by autoclaving for $15 \mathrm{~min}$. at $121^{\circ}$. 
Haematin medium. Haematin (British Drug Houses Ltd., O.I g.) was dissolved in a minimum volume of triethanolamine, made up to $100 \mathrm{ml}$. with distilled water and sterilized by heating to $100^{\circ}$ for $15 \mathrm{~min}$. on two consecutive days. The haematin solution was stored at $4^{\circ}$ and freshly prepared every two months; it was added to the basal medium to give a final concentration of $50 \mu \mathrm{g}$. haematin $/ \mathrm{ml}$.

Partially defined medium. The partially defined medium for Streptococcus faecalis described by Bauchop \& Elsden (I960) was used for growth yield studies.

Washed suspensions. Organisms from liquid media or washed from slopes were centrifuged, washed twice in buffer and resuspended in buffer as required.

Cell-free extracts. Washed suspensions were treated ultrasonically (M.S.E. I00 W ultrasonic generator) in a tube surrounded by ice. The debris and unbroken cocci were removed by centrifugation at $23,000 \mathrm{~g}$ for $30 \mathrm{~min}$.

Broken-cell suspensions were prepared as above but only centrifuged at $3000 \mathrm{~g}$ for Io min., so removing any whole organisms but not the cell debris.

The protein content of extracts was measured by the Folin-Ciocalteu phenol reagent as described by Lowry, Rosebrough, Farr \& Randall (I95I), with crystalline bovine serum albumin as a standard.

Cell membrane preparation. Cell membranes were prepared by the method of Shockman, Kolb, Bakay, Conover \& Toennies (1963), by using lysozyme, osmotic shock and centrifugation.

Manometry. Oxygen uptake was measured by conventional Warburg manometric techniques (Umbreit, Burris \& Stauffer, I95I). The gas phase was air and each flask contained I to $5 \mathrm{mg}$. dry cell wt and $\mathrm{I} 50 \mu$ mole potassium phosphate buffer (pH 6.5) in the main compartment; $0.2 \mathrm{ml}$. of $10 \% \mathrm{KOH}(\mathrm{w} / \mathrm{v})$ with a filter paper wick in the centre well and Io $\mu$ mole of substrate in the side arm, total volume of liquid being made to $2.5 \mathrm{ml}$. with distilled water.

Enzyme assays. The oxidation of reduced pyridine nucleotides (NADH and NADPH) was followed spectrophotometrically on a Unicam S.P. 800 spectrophotometer at $340 \mathrm{~nm}$. Cuvettes contained $\mathrm{I} 3 \mu$ mole glycylglycine buffer $(\mathrm{pH} 7 \cdot 2) ; 3 \mu$ mole potassium phosphate buffer $(\mathrm{pH} 7.2) ; 6 \mu$ mole $\mathrm{MgCl}_{2} ; 3 \mu$ mole $\mathrm{KF} ; 0$. I $5 \mu$ mole NADH (or NADPH) and cell extracts equivalent to $0.5 \mathrm{mg}$. protein; total volume made to $2 \mathrm{ml}$. with distilled water.

The molar extinction coefficient of Horecker \& Kornberg (I948) was used to convert extinction at $340 \mathrm{~nm}$. to molar quantities of reduced pyridine nucleotide.

Adenosine triphosphate was measured by the method of Pinchot (1953). Cuvettes containing the reagents listed above plus $0.03 \mathrm{mg}$. bovine serum albumin; Io $\mu$ mole glucose; $0.3 \mu$ mole ADP or AMP; with or without $0.15 \mu$ mole NADP; 5 units hexokinase (British Drug Houses Ltd., ex-yeast) and I50 units glucose-6-phosphate dehydrogenase were used to detect and measure oxidative phosphorylation coupled to NADH oxidation. ATP was trapped to form glucose-6-phosphate by the enzyme hexokinase and the glucose-6-phosphate was oxidized by glucose-6-phosphate dehydrogenase with a simultaneous reduction of NADP. The rate of reduction of NADP was indicative of the rate of ATP formation. NADP reduction was measured as the difference in the rate of extinction decrease at $340 \mathrm{~nm}$. between cuvettes containing NADP and cuvettes containing no NADP.

In most ATP assays a preparation of glucose-6-phosphate dehydrogenase extracted from Leuconostoc mesenteroides grown anaerobically on glucose was used. Ragland, 
Kawasaki \& Lowenstein (I966) showed that L. mesenteroides has a very high degree of glucose-6-phosphate dehydrogenase activity. A cell free extract of $L$. mesenteroides containing 5 to Io mg. protein $/ \mathrm{ml}$. was treated with $0 . \mathrm{I}$ vol. of $0.25 \mathrm{M}-\mathrm{MnCl}_{2}$, shaken and allowed to stand at room temperature for Io min. The precipitate was removed by centrifugation at $23,000 \mathrm{~g}$ for $10 \mathrm{~min}$. The supernatant fluid was treated with saturated ammonium sulphate and the fraction precipitated between 45 and $60 \%$ saturation was retained for its glucose-6-phosphate dehydrogenase activity. The precipitate was dissolved in $0.02 \mathrm{M}$-tris- $\mathrm{HCl}$ buffer $(\mathrm{pH} 7 \cdot 2)$ and a sample containing $0.2 \mathrm{mg}$. protein used in each cuvette for the assay of ATP.

Lactate dehydrogenase was detected by observing the reduction of 2,3,5-triphenyltetrazolium chloride in the presence of lactate in Thunberg tubes. Each tube contained: I mmole potassium phosphate buffer ( $\mathrm{pH} 7 \cdot 5) ; 6 \mu$ mole NAD; $6 \mu$ mole $2,3,5$-triphenyltetrazolium chloride; I. $3 \mu$ mole $N$-methyl phenazonium methosulphate; Ioo $\mu$ mole DL-sodium lactate and 5 to $10 \mathrm{mg}$. protein; total volume to $10 \mathrm{ml}$. with distilled water. Each tube was evacuated and refilled with nitrogen twice. The reaction was started by tipping in the extracts from the side arm.

Analysis of the products of glucose and lactate fermentation. The fermentation experiments were carried out in a conical flask on a shaking water bath at $30^{\circ}$. A stream of either air or oxygen-free nitrogen was passed through a carbon dioxide trap, the conical flask, a cooled $U$ tube to trap any volatile products and finally through two Drechsel bottles, each containing $50 \mathrm{ml}$. of $0.05 \mathrm{M}-\mathrm{Ba}(\mathrm{OH})_{2}$. Each flask contained 5 mmole potassium phosphate buffer ( $\mathrm{pH}_{6.5}$ ); $100 \mu$ mole of glucose or DL-sodium lactate; $20 \mathrm{mg}$. dry wt cocci; total volume to roo ml. with distilled water.

Residual glucose was measured by the method of Fuller, Lampitt \& Coton (1955) using the reduction of ferricyanide and titration with 0.0 I M-ceric sulphate with xylene cyanol FF as an indicator.

Formic, acetic and lactic acids were separated chromatographically on a silica gel column with a benzene plus butanol gradient solvent (Lessard \& McDonald, I966). The effluent from the column was titrated against $0.0 \mathrm{I}$ M-NaOH using a Radiometer (Denmark) automatic titration and recorder assembly.

Carbon dioxide was absorbed in $0.05 \mathrm{M}-\mathrm{Ba}(\mathrm{OH})_{2}$ in Drechsel bottles and measured by subsequent titration against $\mathrm{O} \cdot \mathrm{I} \mathrm{M}-\mathrm{HCl}$.

Pyruvate was determined by the method of Friedemann \& Haugen (I943), using benzene to extract the phenylhydrazone.

Acetoin was determined by the method of Langlykke \& Peterson (1937).

Growth yield experiments. Aerobic growth yield measurements were made in shallow broth cultures in flasks incubated in a shaking incubator. The partially defined medium of Bauchop \& Elsden (1960) was used and haematin and substrates were added as filter-sterilized solutions. Four flasks were used at each substrate concentration, three of these being used to follow growth and when growth had ceased the contents of the fourth flask were made up to the original volume with distilled water and the extinction of the culture measured with a Unicam S.P. 600 spectrophotometer at $540 \mathrm{~nm}$., and the bacterial dry weight calculated by reference to a dry weight against extinction curve. All growth yields were measured at several substrate concentrations and the results plotted on a graph. Final growth yield results were then calculated from the gradient of the linear portion of the graph. 


\section{RESULTS}

Growth yield experiments. Aerobic and anaerobic growth yields of Streptococcus faecalis were measured (Table I) in the presence and absence of haematin. In the absence of haematin, anaerobic growth yields of $16 \mathrm{~g}$. dry wt/mole glucose and I8 g. dry wt/mole fructose fermented were recorded. Assuming a theoretical yield of 2 moles ATP/mole hexose fermented by homolactic fermentation these figures approximate to a yield of $9 \mathrm{~g}$. dry wt/mole ATP.

Aerobically, glucose and fructose each provided the equivalent of 3 moles ATP/mole hexose. If all the pyruvate, normally reduced to lactate, were oxidized to acetate and $\mathrm{CO}_{2}$, a theoretical yield of 4 mole ATP/mole hexose oxidized would be possible. Chemical analysis of the products of glucose oxidation (Table 8 ) showed $38.5 \%$ of the glucose was converted to lactate and $17 \%$ to acetoin and, assuming the remainder was oxidized via acetyl phosphate to acetate, a yield of 2.9 moles ATP/mole glucose would be expected, which is very close to the experimental ATP yield recorded.

In the presence of haematin a yield of 6 moles ATP/mole hexose oxidized was recorded. This yield exceeded the theoretical maximum of 4 moles ATP/mole hexose and the extra energy was presumed to be produced by oxidative phosphorylation coupled to a haematin enzyme electron transport system. Haematin did not improve anaerobic growth yields. Protoporphyrin IX, the immediate precursor of haematin, did not stimulate in place of haematin. This agrees with Whittenbury (196I) who found only haematin stimulated haematin enzyme formation in lactic acid bacteria and could not be replaced by protoporphyrin IX or ferrous or ferric salts.

Assuming that energy was obtained from oxidative phosphorylation, a greater growth yield would be expected with lactate than with pyruvate, aerobically in the presence of haematin, because of the extra pair of electrons on lactate. This was found to be the case. No growth was obtained anaerobically with acetate, pyruvate or lactate.

London (I968) grew Streptococcus faecium with lactate as sole energy source. The growth yield with lactate for $S$. faecalis under aerobic conditions (Table I) was slightly greater than the yield of $S$. faecium obtained by London. Aerobic growth on lactate in the absence of haematin is presumably at the expense of energy obtained from pyruvate breakdown following the oxidation of lactate to pyruvate. In the presence of haematin, growth yields of $S$. faecalis obtained aerobically were much greater than in the absence of haematin. The stimulatory effect of haematin again indicated the occurrence of oxidative phosphorylation.

Manometric measurement of oxygen uptake. Streptococcus faecalis grown on media with added haematin took up oxygen more rapidly than did $S$. faecalis grown without haematin (Table 2). The considerable oxygen uptake on pyruvate and lactate by haematin-grown cocci probably accounted for the extra oxygen used on glucose by these same cells.

Since Streptococcus faecalis grew readily with lactate as an energy source when incubated aerobically in the presence of haematin, the oxygen uptake of these organisms with lactate and glucose was tested. The results (Table 2) showed that whilst cocci grown with haematin and either glucose or lactate had the same rate of oxygen uptake on glucose, the lactate-grown cocci showed a faster rate of oxygen uptake on lactate than did the glucose-grown cocci, indicating that the lactate-oxidizing enzyme system may be inducible. 
From the analysis of the products of glucose and lactate oxidation by Streptococcus faecalis (Table 8) it seemed that some of the substrate, particularly glucose, was fermented. Some of the pyruvate from lactate breakdown was not oxidized to acetate but fermented to acetoin. Therefore, the figures for $\mathrm{O}_{2} \mathrm{used} / \mathrm{mole}$ of these substrates metabolized oxidatively are lower than if only pathways using oxygen as a terminal electron acceptor had been used. These results again indicate the active participation of haematin enzyme(s) in oxidation.

Table I. Molar growth yields obtained with Streptococcus faecalis

For cultural details see test.

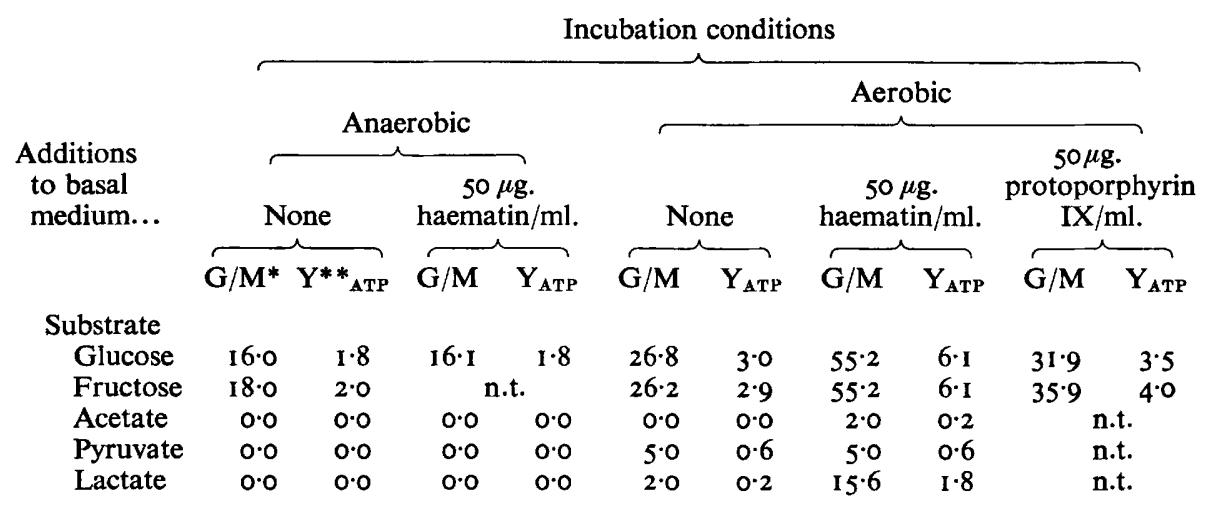

* $\mathrm{G} / \mathrm{M}=$ dry weight cocci in $\mathrm{g} . /$ mole of substrate.

** $\mathrm{Y}_{\mathrm{A}^{\prime} \mathrm{TP}}=$ mole ATP $/ \mathrm{mole}$ of substrate, calculated from the $\mathrm{G} / \mathrm{M}$ figure assuming an average of 9.0 g. dry weight cocci/mole ATP.

n.t. $=$ not tested.

Table 2. Manometric measurements of oxygen uptake by resting suspensions of Streptococcus faecalis with several substrates

\begin{tabular}{|c|c|c|c|c|}
\hline \multirow{2}{*}{$\begin{array}{l}\text { Growth con- } \\
\text { ditions of cocci... }\end{array}$} & \multicolumn{4}{|c|}{$\mu \mathrm{l} . \mathrm{O}_{2}$ uptake/mg. dry wt cocci/hr } \\
\hline & $\begin{array}{c}\text { Aerobic } \\
\text { with glucose }\end{array}$ & $\begin{array}{l}\text { Anaerobic } \\
\text { with glucose }\end{array}$ & $\begin{array}{c}\text { Aerobic with } \\
\text { glucose } \\
+ \\
\text { haematin }\end{array}$ & $\begin{array}{c}\text { Aerobic with } \\
\text { lactate } \\
+ \\
\text { haematin }\end{array}$ \\
\hline \multicolumn{5}{|l|}{ Substrate } \\
\hline None & 0.16 & 0.15 & 0.35 & 0.30 \\
\hline Glucose & $\begin{array}{l}44 \cdot 7 \\
(I \cdot 1)\end{array}$ & $\begin{array}{l}28 \cdot 6 \\
(0 \cdot 7)^{*}\end{array}$ & $\begin{array}{l}56 \cdot 6 \\
(I \cdot 4)\end{array}$ & $\begin{array}{l}58 \cdot 2 \\
(1 \cdot 4)\end{array}$ \\
\hline Acetate & 0.15 & n.t. & 0.43 & n.t. \\
\hline Pyruvate & 0.42 & n.t. & 0.92 & n.t. \\
\hline Lactate & 0.35 & n.t. & $2 \cdot 90$ & 12.4 \\
\hline
\end{tabular}

n.t. $=$ not tested.

* Figures in parentheses with glucose as a substrate represent the mole oxygen consumed/mole substrate.

Oxidation of reduced pyridine nucleotides. The figures in Table 3 show that most of the NADH-oxidizing enzymes in cocci grown in the presence of haematin were associated with the cell membranes. Extracts of the haematin-grown cocci had a higher level of NADH oxidases than did extracts of cocci grown without haematin. Also the NADH-oxidizing activity of the extracts of haematin-grown cocci was sensitive to 
cyanide. A crudely prepared membrane fraction, containing cell membranes, cell debris and soluble proteins, but with whole cocci removed by centrifugation, was the most convenient fraction for the study of the oxidation of reduced pyridine nucleotides.

Table 3. NADH and NADPH oxidation by extracts of Streptococcus faecalis grown aerobically with or without haematin

\begin{tabular}{|c|c|c|c|c|c|c|}
\hline \multirow[b]{2}{*}{ Preparation } & & \multicolumn{5}{|c|}{$\begin{array}{c}\mathrm{m} \mu \text { mole reduced pyridine nucleotide } \\
\text { oxidized } / \mathrm{min} . / \mathrm{mg} \text {. protein }\end{array}$} \\
\hline & $\begin{array}{l}\text { Additions } \\
\text { to the } \\
\text { growth } \\
\text { medium }\end{array}$ & NADPH & NADH & $\begin{array}{l}\text { NADH } \\
\text { with } \\
\mathrm{IO}^{-2} \mathrm{M}- \\
\mathrm{KCN}\end{array}$ & $\begin{array}{c}\text { NADH } \\
\text { with } \\
\mathrm{IO}^{-2} \mathrm{M}- \\
\mathrm{NaN}_{3}\end{array}$ & $\begin{array}{c}\text { NADH } \\
\text { with } \\
1.6 \times 10^{-4} \\
\text { Anti- } \\
\text { mycin A }\end{array}$ \\
\hline Cell-free extract & - & $\begin{array}{r}I \\
0.76\end{array}$ & $5 \cdot 21$ & & 10.00 & n.t. \\
\hline $\begin{array}{l}\text { Cell-free extract } \\
\text { Membrane }\end{array}$ & $\begin{array}{l}50 \mu \mathrm{g} \text {. haematin } / \mathrm{ml} \text {. } \\
50 \mu \mathrm{g} \text {, haematin } / \mathrm{ml} \text {. }\end{array}$ & $\begin{array}{l}0.76 \\
\text { n.t. }\end{array}$ & $\begin{array}{r}17.6 \\
505.0\end{array}$ & $\begin{array}{l}3.01 \\
28.8\end{array}$ & $\begin{aligned} 14.56 \\
516.0\end{aligned}$ & $\begin{aligned} \text { n.t. } \\
468 \cdot 0\end{aligned}$ \\
\hline preparation & 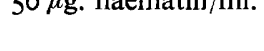 & & & & & \\
\hline
\end{tabular}

Table 4. Control experiments prior to ATP assay during NADH oxidation by extracts of Streptococcus faecalis

The complete reaction system for the assay of ATP contained I $3 \mu$ mole glycylglycine buffer, $\mathrm{pH} 7 \cdot 2 ; 3 \mu$ mole potassium phosphate buffer, $\mathrm{pH} 7 \cdot 2 ; 6 \mu$ mole $\mathrm{MgCl}_{2} ; 3 \mu$ mole $\mathrm{KF}$; $0.15 \mu$ mole NADH; cocci extract, $0.5 \mathrm{mg}$. protein; $0.03 \mathrm{mg}$. bovine serum albumin; with or without $0.15 \mu$ mole NADP; $0.3 \mu$ mole ADP or AMP; 5 units hexokinase and 150 units glucose-6-phosphate dehydrogenase, total vol. to $2 \mathrm{ml}$. with distilled water.

System being tested

Reduction of NADP by

$S$. faecalis extract

Reduction of NAD by

S. faecalis extract

Enzymic ATP assay system controls (with NAD)

Enzymic ATP assay system controls (with NADP)
Added to basic buffer system (concentrations as in the complete ATP assay system shown above)

NADP, extract, glucose

NADP, extract, glucose, ADP

NADP, extract, glucose, ADP, hexokinase

NAD, extract, glucose

NAD, extract, glucose, ADP

NAD, extract, glucose, ATP

NAD, extract, glucose, ATP, G-6-P dehydrogenase, hexokinase

NAD, extract, glucose, ATP, G-6-P dehydrogenase, $\quad 4 \mathrm{I} \cdot 6$ hexokinase, NADP ( - ve control)

NADP, glucose, ADP

NADP, glucose, ADP, extract

NAD, extract, ADP, glucose

NAD, extract, ATP, glucose

NADP, extract, ATP (-ve control), glucose $\mu$ mole

NAD or

NADP

reduced/

$\mathrm{min} . / \mathrm{mg}$.

protein

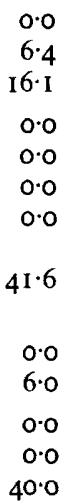

$6 \cdot 4$

$6 \cdot 1$

$0 \cdot 0$

$0 \cdot 0$

0.0

$0 \cdot 0$

0.0

0.0

$40 \cdot 0$

Oxidative phosphorylation during oxidation of reduced pyridine nucleotides. Before attempting to detect ATP during NADH oxidation by extracts of Streptococcus faecalis, control experiments were made on all components of the reaction mixture (Table 4). Reduction of NADP by the $S$. faecalis extract in the presence of glucose and ADP showed that a myokinase activity generating ATP was present. When excess 
ADP was present in the ATP assay system there was a steady ATP production due to myokinase activity for which a correction was made when ATP was formed during NADH oxidation. The ATP assay system did not reduce NAD in the presence of ATP with or without the $S$. faecalis extract in the system.

The G-6-P dehydrogenase preparation derived from Leuconostoc mesenteroides extracts gave similar results to commercial (British Drug Houses Ltd.) G-6-P dehydrogenase except for a slight myokinase activity in the former for which a correction was made along with the $S$. faecalis myokinase activity.

\section{Table 5. Comparison of oxidative phosphorylation in extracts of Streptococcus faecalis grown under various conditions}

\begin{tabular}{|c|c|c|c|c|c|}
\hline \multicolumn{6}{|c|}{ Complete reaction system as outlined for Table 4.} \\
\hline & \multirow{2}{*}{$\begin{array}{c}\text { Additions } \\
\text { to the } \\
\text { basal medium }\end{array}$} & \multirow[b]{2}{*}{$\begin{array}{l}\text { Reaction } \\
\text { system }\end{array}$} & \multicolumn{2}{|c|}{$\underset{\text { protein }}{\mathrm{m} \mu \mathrm{mole} / \mathrm{min}} / \mathrm{mg}$} & \\
\hline & & & $\begin{array}{l}\text { NADH } \\
\text { oxidized }\end{array}$ & $\begin{array}{l}\text { NADP } \\
\text { reduced }\end{array}$ & $\mathrm{P}: \mathrm{O}$ \\
\hline \multirow{8}{*}{$\begin{array}{l}\text { Broken cell } \\
\text { preparations } \\
\text { of cocci grown } \\
\text { aerobically }\end{array}$} & Glucose + & Complete & $215 \cdot 0$ & $73 \cdot 0$ & 0.34 \\
\hline & haematin & Complete & $189 \cdot 2$ & $64 \cdot 4$ & 0.34 \\
\hline & & Complete & $202 \cdot 0$ & $64 \cdot 7$ & 0.32 \\
\hline & Glucose & Complete & $90 \cdot 0$ & 0.0 & $0 \cdot 0$ \\
\hline & & Complete & $95 \cdot 0$ & 0.0 & 0.0 \\
\hline & Lactate+ & Complete & $53 \cdot 2$ & 15.0 & 0.28 \\
\hline & haematin & $\begin{array}{l}\text { AMP in place } \\
\text { of ADP }\end{array}$ & $48 \cdot 5$ & $9 \cdot 7$ & 0.20 \\
\hline & & $\begin{array}{l}\text { AMP in place } \\
\text { of ADP }\end{array}$ & $48 \cdot 8$ & $7 \cdot 2$ & 0.15 \\
\hline \multirow{2}{*}{$\begin{array}{l}\text { Broken cell } \\
\text { preparations } \\
\text { of cocci grown } \\
\text { anaerobically }\end{array}$} & $\begin{array}{c}\text { Glucose }+ \\
\text { haematin }\end{array}$ & Complete & $54 \cdot 5$ & 0.0 & 0.0 \\
\hline & Glucose & Complete & $57 \cdot 8$ & 0.0 & 0.0 \\
\hline
\end{tabular}

Extracts of Streptococcus faecalis grown on media containing haematin produced ATP during oxidation of NADH whilst cocci grown in media without haematin did not produce ATP during NADH oxidation (Table 5). A P:O ratio of about 0.3 was found, which decreased to 0.15 to 0.20 when AMP replaced ADP in the reaction mixture. The lack of oxidative phosphorylation by extracts of cocci grown without haematin contrasts with the results obtained by Gallin \& Vandemark (I964) who showed ATP production during NADH oxidation by extracts of $S$. faecalis grown without haematin. Extracts prepared from $S$. faecalis grown anaerobically in the presence or absence of haematin showed no detectable phosphorylation coupled to NADH oxidation.

Effects of inhibitors of oxidative phosphorylation on Streptococcus faecalis extracts. Sodium azide, potassium cyanide and Antimycin A were used. With $\mathrm{I} \times \mathrm{IO}^{-2} \mathrm{M}$-cyanide there was a $59 \%$ inhibition of NADH oxidation by extracts of haematin-grown cells and a $74 \%$ decrease in the $\mathrm{P}: \mathrm{O}$ ratio; with $3 \times 10^{-2} \mathrm{M}$-cyanide phosphorylation was completely inhibited while NADH oxidation was decreased to $6 \%$ of the original rate (Table 6). With $\mathrm{I} \times \mathrm{IO}^{-2} \mathrm{M}-\mathrm{NaN}_{3}$ there was only an $8 \%$ decrease in $\mathrm{NADH}$ oxidation and no decrease in the $\mathrm{P}: \mathrm{O}$ ratio. Sodium azide at $\mathrm{I} \cdot 5 \times 1 \mathrm{I}^{-2} \mathrm{M}$ resulted in an $18 \%$ inhibition of $\mathrm{NADH}$ oxidation but a slightly increased $\mathrm{P}: \mathrm{O}$ ratio. These 
results contrast with those obtained by Gallin \& Vandemark (1964) who detected no inhibition of oxidative phosphorylation in their $S$. faecalis extracts in presence of cyanide or azide. They used lower concentrations $\left(4 \times \mathrm{IO}^{-4} \mathrm{M}-\mathrm{KCN}, \mathrm{I} \times \mathrm{IO}^{-4} \mathrm{M}-\mathrm{NaN}_{3}\right)$ which might account for the difference. It would seem that Gallin \& Vandemark were measuring a different type of oxidative phosphorylation from the one being assayed in the present work.

Table 6. Effects of various inhibitors of oxidative phosphorylation on extracts of Streptococcus faecalis grown aerobically on glucose plus haematin

ATP assay system as described for Table 4.

\begin{tabular}{|c|c|c|c|c|c|}
\hline \multirow[b]{2}{*}{ Extract } & \multirow[b]{2}{*}{ Inhibitor } & \multirow[b]{2}{*}{$\begin{array}{l}\text { Concentration } \\
\text { (molar) }\end{array}$} & \multicolumn{2}{|c|}{$\underset{\text { protein }}{\mathrm{m} \mu \mathrm{mole} / \mathrm{min}} / \mathrm{mg}$. } & \\
\hline & & & $\begin{array}{l}\text { NADH } \\
\text { oxidized }\end{array}$ & $\begin{array}{l}\text { NADP } \\
\text { reduced }\end{array}$ & $P: O$ \\
\hline $\begin{array}{l}S, \text { faecalis } \\
\text { broken-cell } \\
\text { preparation }\end{array}$ & $\begin{array}{l}\text { None } \\
\mathrm{KCN} \\
\mathrm{KCN} \\
\mathrm{NaN}_{3} \\
\mathrm{NaN}_{3}\end{array}$ & $\begin{array}{l}\quad- \\
1 \times 10^{-2} \\
3 \times 10^{-2} \\
1 \times 10^{-2} \\
1 \cdot 5 \times 10^{-2}\end{array}$ & $\begin{array}{r}215 \cdot 0 \\
88 \cdot 2 \\
12.8 \\
197 \cdot 0 \\
176 \cdot 0\end{array}$ & $\begin{array}{r}73 \cdot 0 \\
7 \cdot 9 \\
0 \cdot 0 \\
58 \cdot 2 \\
74 \cdot 8\end{array}$ & $\begin{array}{l}0.34 \\
0.09 \\
0.0 \\
0.30 \\
0.42\end{array}$ \\
\hline $\begin{array}{l}S . \text { faecalis } \\
\text { membrane } \\
\text { preparation }\end{array}$ & $\begin{array}{l}\text { None } \\
\text { Antimy- } \\
\text { cin A }\end{array}$ & $1 . \overline{6 \times 10^{-4}}$ & $\begin{array}{l}505 \cdot 0 \\
468 \cdot 0\end{array}$ & $\begin{array}{r}221 \cdot 0 \\
0.0\end{array}$ & \\
\hline
\end{tabular}

Antimycin A ( $\left.1 \cdot 6 \times 10^{-4} \mathrm{M}\right)$ completely inhibited oxidative phosphorylation by our Streptococcus faecalis extracts although $90 \%$ of the NADH-oxidizing activity remained. Gallin \& Vandemark (1964) obtained a decreased P:O ratio with $8 \times 10^{-4} \mathrm{M}$ Antimycin A. Some observers (Smith 1954; Breummer, Wilson, Glenn \& Crane, 1957; Lightbown \& Jackson, I956) have noted a lack of sensitivity to Antimycin A amongst bacterial oxidative phosphorylation systems. However our $S$. faecalis system was sensitive to this antibiotic and perhaps it is significant here that a cell-free system was used.

The effect of adding haematin to extracts of Streptococcus faecalis grown in the absence of haematin. An experiment was made to test whether there was any preformed enzyme in S. faecalis grown without haematin, which, on addition of haematin to an extract, would form the haematin-enzyme NADH oxidase system. Several workers have noted a preformed apoenzyme of catalase in organisms unable to synthesize haematin, the catalase being activated when haematin was added to the cocci (Whittenbury, 1965) or to a cell-free extract (Beljanski \& Beljanski, 1957). A broken-cell preparation of $S$. faecalis grown aerobically with glucose was incubated with haematin for $30 \mathrm{~min}$. at $30^{\circ}$ and then tested for oxidative phosphorylation during NADH oxidation. None was detected. This experiment served as a control for other tests reported here in that it showed that the activities claimed for haematin-enzyme systems were not attributable to the haematin alone.

Division of oxidative phosphorylation between different fractions of Streptococcus faecalis extracts. Activities of soluble and particulate fractions of Streptococcus faecalis extracts were compared to determine in which fractions the haematin enzymes occurred. S. faecalis grown aerobically with lactate +haematin were broken ultra- 
sonically and whole cocci and debris removed by centrifugation at $3000 \mathrm{~g}$ for $10 \mathrm{~min}$. Of the NADH oxidizing activity, $88 \%$ was in the supernatant fluid which contained soluble enzymes and cell membranes. This finding agrees with results obtained with cell membranes prepared by treatment of cocci with lysozyme (Table 3 ).

The soluble fraction + membrane fraction was centrifuged at $23,000 \mathrm{~g}$ for $30 \mathrm{~min}$. to precipitate the membranes which were resuspended in $0.05 \mathrm{M}$-potassium phosphate buffer ( $\mathrm{pH} 6.5)$. The myokinase activity noted earlier was mainly in the soluble fraction so that when ATP production by membrane fractions was studied possible error due to this enzyme was decreased.

Table 7. Division of NADH oxidizing enzymes between soluble and membrane fractions of Streptococcus faecalis extracts

\begin{tabular}{|c|c|c|c|c|}
\hline \multirow{2}{*}{$\begin{array}{l}\text { Cocci grown } \\
\text { on basal } \\
\text { medium with }\end{array}$} & \multirow[b]{2}{*}{ Fraction } & & \multirow[b]{2}{*}{ P:O } \\
\hline & & $\begin{array}{c}\text { NADH } \\
\text { oxidized }\end{array}$ & $\begin{array}{l}\text { NADP } \\
\text { reduced }\end{array}$ & \\
\hline \multirow{4}{*}{$\begin{array}{l}\text { Glucose }+ \\
\text { haematin }\end{array}$} & Soluble fraction & $294^{\circ} 0$ & $77 \cdot 0$ & 0.26 \\
\hline & Membrane fraction & $650 \cdot 0$ & $195^{\circ} 0$ & 0.30 \\
\hline & $\begin{array}{l}\text { Soluble fraction* }+ \\
\text { membrane fraction }\end{array}$ & $432 \cdot 0$ & $138 \cdot 3$ & 0.32 \\
\hline & $\begin{array}{l}\text { Soluble fraction } \\
\text { (spun at } \mathrm{I} \mathrm{I} 0,000 \mathrm{~g}\end{array}$ & $\begin{array}{r}89 \cdot 5 \\
\text { o min.) }\end{array}$ & $14: 3$ & 0.16 \\
\hline \multirow{3}{*}{$\begin{array}{l}\text { Lactate }+ \\
\text { haematin }\end{array}$} & Soluble fraction & $191 \cdot 0$ & $52 \cdot 1$ & 0.27 \\
\hline & Membrane fraction & 109.0 & $46 \cdot 5$ & 0.43 \\
\hline & $\begin{array}{l}\text { Soluble fraction* }+ \\
\text { membrane fractior }\end{array}$ & $201 \cdot 0$ & 90.5 & 0.45 \\
\hline
\end{tabular}

\footnotetext{
* In these determinations the soluble fraction and the membrane fraction were mixed in a ratio of $\mathrm{I} \cdot 0: 0 \cdot 8$ of wt of protein.
}

Table 7 shows the results of experiments to determine the site of oxidative phosphorylation within the cell. The membrane fraction of cocci grown with glucose + haematin had a higher NADH oxidase activity than did the soluble fraction although the $\mathrm{P}: \mathrm{O}$ ratio was only slightly greater in the former fraction. Ultracentrifugation (I 10,000 $\mathrm{g}$ for $30 \mathrm{~min}$.) further decreased the rate of NADH oxidation by the soluble fraction and decreased the $\mathrm{P}: \mathrm{O}$ ratio to half the value found for the membrane fraction. The decreased $\mathrm{P}: \mathrm{O}$ ratio in the soluble fraction suggested that there was an $\mathrm{NADH}$ oxidizing system in this fraction not coupled to oxidative phosphorylation. Cocci grown with lactate + haematin gave similar $\mathrm{P}: \mathrm{O}$ ratios. This preparation was not ultracentrifuged.

Reduction of cytochrome pigments in the extracts. With cyanide $\left(\mathrm{I} \times \mathrm{IO}^{-2} \mathrm{M}-\mathrm{KCN}\right)$ and an excess of $\mathrm{NADH}$, peaks of reduced cytochrome were detected in membrane fractions of Streptococcus faecalis grown aerobically with lactate or glucose in the presence of haematin. A typical spectrum is shown in Fig. I, the peaks of which are similar to a ' $b$ ' type cytochrome. There was also an oxidized peak at $412 \mathrm{~nm}$., typical of a cytochrome $b$.

No water-soluble cytochrome was detected and attempts to isolate cytochrome oxidase by using sodium cholate extraction techniques (Yonetani, I960) were unsuccessful. When haematin ( $15 \mu \mathrm{g} . / \mathrm{ml}$.) was added to a broken-cell preparation of 
cocci grown aerobically with glucose no cytochrome peaks were observed. Haematin itself gave a weak peak at $425 \mathrm{~nm}$. but this was not increased or otherwise altered by cyanide, NADH or Streptococcus faecalis enzymes, indicating that the cytochrome peaks were not simply due to haematin from the growth medium.

Oxygen was shown to be necessary for the formation of the cytochromes: extracts of cocci grown anaerobically in the presence of haematin gave no cytochrome peaks.

Oxidation of lactate coupled to ATP production. In an experiment in Thunberg tubes, 2,3,5-triphenyltetrazolium chloride (TTC) was reduced in the presence of lactate only by extracts of haematin-grown cocci; there was no reduction in the absence of lactate.

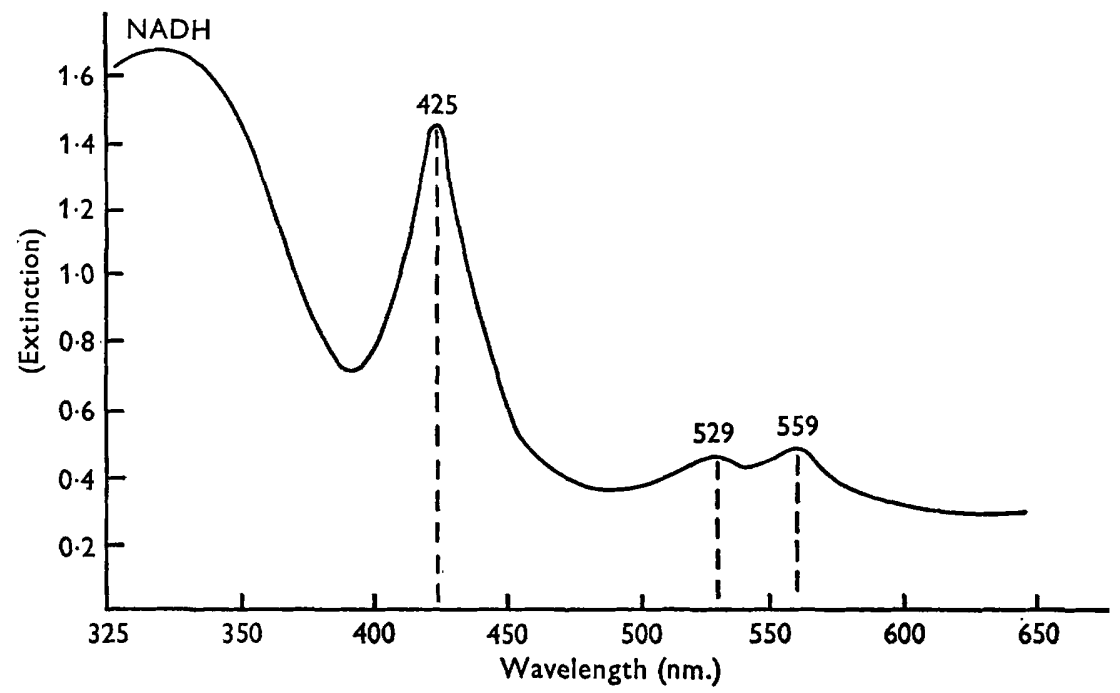

Fig. I. Difference spectrum of a broken-cell suspension of Streptococcus faecalis grown aerobically on glucose + haematin. The sample cuvette contained the broken-cell suspension reduced with excess NADH in the presence of $\mathrm{KCN}\left(\mathrm{IO}^{-2} \mathrm{M}\right)$ and $\mathrm{ADP}$ (I mM). The reference cuvette contained a broken-cell suspension alone. The spectrum was plotted using an SP 800 recording spectrophotometer at room temperature $\left(21^{\circ}\right)$ and with a light path of $\mathrm{I} O \mathrm{~mm}$.

Difficulty was encountered in demonstrating reduction of NAD in the presence of lactate because of the very active NADH oxidases present in the extracts. However, with lactate $(5 \mu \mathrm{mole} / \mathrm{ml}$.) the rate of NADH oxidation by an extract of Streptococcus faecalis, prepared from cocci grown aerobically with lactate + haematin was decreased. The rate of NADP reduction was measured in cuvettes containing the ATP assay system, ATP, $S$. faecalis extract (lactate + haematin grown), AMP, NAD and with or without lactate. Without lactate the rate of NADP reduction was $6.5 \mathrm{~m} \mu \mathrm{mole} / \mathrm{min}$. and with lactate present this rate increased to $7.7 \mathrm{~m} \mu \mathrm{mole} / \mathrm{min}$. NADP was not reduced without the ATP assay system. These differences in rate of NADP reduction and NADH oxidation when lactate was present or absent indicate that reduction of NAD to NADH was coupled to lactate oxidation and that the resulting NADH was subsequently oxidized with the formation of ATP from oxidative phosphorylation. The oxidation of lactate in this fashion appeared to require ATP to initiate the reaction, although the final result was a net gain of ATP. 
Products of glucose and lactate breakdown. Washed suspensions of Streptococcus faecalis grown aerobically without haematin converted $94 \%$ of glucose to lactate under anaerobic conditions, but aerobically only $37.5 \%$ of glucose was converted to lactate (Table 8). The remainder of the pyruvate, which would otherwise have been reduced to lactate, was either oxidized to acetate and $\mathrm{CO}_{2}$ or fermented to acetoin and $\mathrm{CO}_{2}$. Cocci grown aerobically on glucose + haematin converted only $14 \%$ of the glucose into lactate. Cocci grown aerobically on lactate plus haematin converted $\mathrm{I} 3 \%$ of glucose to lactate and also oxidized lactate to produce $\mathrm{CO}_{2}$, acetate and acetoin.

\section{Table 8. Products of glucose and lactate oxidation by washed} Streptococcus faecalis

All cocci were grown aerobically.

Incubation conditions in experiment*

\begin{tabular}{|c|c|c|c|c|c|}
\hline $\begin{array}{c}\text { Growth substrate } \\
\ldots\end{array}$ & $\begin{array}{l}\text { Anaerobic } \\
\text { with } \\
\text { glucose }\end{array}$ & $\begin{array}{l}\text { Aerobic } \\
\text { with } \\
\text { glucose }\end{array}$ & $\begin{array}{c}\text { Aerobic } \\
\text { with glucose }+ \\
\text { haematin }\end{array}$ & $\begin{array}{c}\text { Aerobic } \\
\text { with lactate }+ \\
\text { haematin }\end{array}$ & $\begin{array}{c}\text { Aerobic } \\
\text { with lactate }+ \\
\text { haematin }\end{array}$ \\
\hline
\end{tabular}

$\begin{array}{lrrrrr}\begin{array}{l}\text { Oxidation substrates } \\ \text { Glucose }\end{array} & 100 & 100 & 100 & 100 & - \\ \begin{array}{l}\text { Lactate } \\ \text { Oxidation products }\end{array} & - & - & - & - & \text { I00 } \\ \text { Lactate } & 187 & 77 & 29 & 25 & - \\ \text { Acetate } & 0 & 64 & 61 & 108 & 38 \\ \text { Formate } & 0 & 0 & 8 & 4 & 0 \\ \text { Pyruvate } & 3 & 1 & 3 & 4 & 9 \\ \text { CO } & 6 & 130 & 171 & 153 & 9 \text { I } \\ \text { Acetoin } & - & 26 & 43 & 10 & 23 \\ \text { C recovery }(\%) & 96 & 99 & 95 & 101 & 95\end{array}$

* 100 mole of each substrate were added and the concentrations of the products are expressed as mole/100 mole of substrate.

\section{DISCUSSION}

The evidence presented points conclusively to the development of a pathway in Streptococcus faecalis grown aerobically with haematin in which the oxidation of NADH is catalysed by haematin enzyme(s) and is coupled to oxidative phosphorylation. Gallin \& Vandemark (I964) showed oxidative phosphorylation in S. faecalis strain IOC I and suggested that potential sites for phosphorylation were at the NADH/flavin level and at the point of oxidation of reduced naphthoquinone. Their experiments were concerned with a phosphorylation which was insensitive to cyanide and to azide. The present work, however, has revealed no oxidative phosphorylation of this type in $S$. faecalis grown without haematin.

The $\mathrm{P}: \mathrm{O}$ ratios observed in the present work were relatively low, the highest value being 0.44 , in comparison with the work of Pinchot (1953) who reported a P:O ratio of 0.78 in Alcaligenes faecalis and of Hartmann, Brodie \& Gray (I957) who reported a P:O ratio approaching $\mathrm{I}$ in Azotobacter vinelandii extracts. The value of the $\mathrm{P}: \mathrm{O}$ ratio for Streptococcus faecalis, and the results of experiments when the soluble and membrane fractions were examined separately and together, suggested that there was only one site of phosphorylation coupled to NADH oxidation in $S$. faecalis extracts. It is known that the preparation of extracts affects the activity of the sites of oxidative 
phosphorylation. Racker (1965) noted that the preparation of submitochondrial particles by ultrasonic treatment and mechanical fragmentation decreased the efficiency of phosphorylation sites, and especially of the site coupled to the oxidation of cytochrome $c$ and to a lesser extent of the site coupled to the oxidation of NADH by flavoproteins. The third site, coupled to the oxidation of cytochrome $b$ was relatively unaffected. Antimycin A inhibits at the level of this last mentioned site (Racker, 1965) and this could well be the site in operation in $S$. faecalis extracts.

Growth yield measurements in experiments with Streptococcus faecalis on glucose where oxygen uptake was measured manometrically (with $\mathrm{Hg}$. as a manometer fluid replacing Brodie solution) yielded a figure of $0.16 \mathrm{~g}$. dry wt/g. oxygen used, a low figure in comparison to the $0.853 \mathrm{~g}$. dry wt/g. oxygen used found by Hernandez \& Johnson (1967) with Pseudomonas fluorescens. The lower growth yield with $S$. faecalis again points to only one phosphorylation site; Hernandez \& Johnson suggested that the pseudomonad probably has up to three oxidative phosphorylation sites.

Assuming only one oxidative phosphorylation site it is possible to account for the production of I mole ATP/mole NADH oxidized. Ideally, 4 mole ATP are obtainable from glycolysis and pyruvate oxidation. If the 2 mole NADH produced/mole glucose oxidized and the 2 mole of NADH produced/mole pyruvate oxidized are oxidized via the haematin enzymes, a potential yield of 8 mole ATP/mole glucose oxidized can be expected. Experimentally a yield of $6.5 \mathrm{~mole}$ ATP/mole glucose oxidized was obtained. This less than maximum yield was partly accounted for by the presence of lactate and acetoin amongst the products of glucose oxidation, showing some competition from fermentative pathways. In addition some NADH is probably oxidized by the Streptococcus faecalis flavoprotein/NADH oxidases (Dolin, 1955) as shown by the residual rate of NADH oxidation in the presence of cyanide. This oxidation would also partly account for the low $\mathrm{P}: \mathrm{O}$ ratio.

The spectrum of the reduced cytochrome pigment of the Streptococcus faecalis extract was very similar to cytochrome $b_{2}$ of yeast as reported in the yeast lactate dehydrogenase system by Appleby \& Morton (1959). A strain of S. faecalis (H.69.D 5) has been shown to form cytochromes $b, a$ and $a_{2}$ (Whittenbury, 1964). No $a$-type cytochrome was detected in the present study, either in a difference spectrum or by a cholate extraction technique (Yonetani, 1960). The terminal oxidase was cyanide sensitive as with cyanide the cytochrome $b_{2}$ was reduced by NADH but not oxidized.

These results raise interesting evolutionary and taxonomic questions. The appearance of residual, either degenerate or undeveloped, aerobic pathways suggests that the dividing line between, say, streptococci and staphylococci may be less than at first appears to be the case.

Even though the presence of haematin stimulates Streptococcus faecalis to behave like an aerobe, it still performs inefficiently in that a functional Krebs cycle is lacking and final products of glucose oxidation include lactate, acetate and acetoin. Perhaps apoenzymes of missing enzymes may be present in some strains of $S$. faecalis and in future studies a 'complete' aerobe may be resurrected with the aid of preformed prosthetic groups. On present evidence it would seem that $S$. faecalis, and possibly the other lactic acid bacteria, are metabolic 'cripples' capable of being useful experimental models in the study of the evolution and the mechanism of aerobic metabolism. 
We wish to thank the Agricultural Research Council for its support during this investigation.

\section{REFERENCES}

AppleBy, C. A. \& MoRTon, R. K. (1959). Lactic dehydrogenase and cytochrome $b_{2}$ of bakers yeast and chemical properties of the crystalline enzyme. Biochem.J. 73, 539.

BaUCHOP, R. \& ElSDEN, S. (1960). The growth of microorganisms in relation to their energy supply. J. gen. Microbiol. 23, 457.

BAUM, R. A. \& Dolin, M. (I963). Isolation of a new napthoquinone from Streptococcus faecalis IOC I. J. biol. Chem. 238, PC 4109.

Beljanski, M. \& BelJanski, M. (1957). Sur la formation d'enzymes respiratoires chez un mutant d'Escherichia coli streptomycino-resistant et auxotrophe pour l'hemine. Annls Inst. Pasteur, Paris 92, 396.

Breummer, J. H., Wilson, P. W., GlenN, J. L. \& Crane, F L. (1957). Electron transporting particle from Azotobacter vinelandii. J. Bact. 73, 113.

Dolin, M. J. (1953). The oxidation and peroxidation of DPNH in extracts of Streptococcus faecalis IOC I. Archs. Biochem. Biophys. 46, 483.

DolIN, M. J. (I955). The DPNH-oxidising enzymes of Streptococcus faecalis. II. The enzymes utilising $\mathrm{O}_{2}$, cytochrome $c$, peroxide and 2,6-dichlorophenol-indophenol or ferricyanide as oxidants. Archs Biochem. Biophys. 55, 415.

Friedemann, T. E. \& Haugen, G. E. (I943). Determination of pyruvic acid. J. biol. Chem. 147, I45.

Fuller, C. H. F., LAMPITT, L. H. \& Coton, L. (I955). Studies in starch structure. I. Analytical methods. J. Sci. Fd Agric. 6, 656.

Gallin, J. I. \& Vandemark, P. J. (1964). Evidence for oxidative phosphorylation in Streptococcus faecalis. Biochem. biophys. Res. Commun. 17, 630.

Hartmann, P. E., Brodie, A. F. \& Gray, C. T. (1957). Coupled oxidative phosphorylation in crude extracts of Azotobacter. J. Bact. 74, 319.

HeRnandez, E. \& Johnson, M. T. (1967). Energy supply and cell yield in aerobically grown microorganisms. J. Bact. 94, 966.

HORECKER, B. L. \& KorNBERG, A. (1948). The extinction coefficients of the reduced band of pyridine nucleotides. J. biol. Chem. 175, 385 .

LANGlykKe, A. E. \& Peterson, W. M. (I937). Determination of acetylmethylcarbinol. Ind. Engng Chem. analyt. Edn 9, 163.

LessaRD, J. R. \& MCDONALD, P. (1966). A silica gel chromatographic procedure adapted to liquid scintillation counting of $\mathrm{C}^{14}$ labelled organic acids from plant material and silage. $J$. Sci. Fd Agric. 17, 257.

LightBown, J. W. \& JACKson, F. J. (1956). Inhibition of cytochrome systems of heart muscle and certain bacteria by the antagonists of dihydrostreptomycin: 2-alkyl-4-hydroxyquinoline $\mathrm{N}$-oxides. Biochem. J. 63, 130.

LoNDON, J. (1968). Regulation and function of lactate oxidation in Streptococcus faecium. J. Bact. 95, I380.

Lowry, O. H., Rosebrough, N. J., FarR, A. L. \& Randall, R. J. (I95I). Protein measurement with the Folin phenol reagent. J. biol. Chem. I93, 265.

PINChot, G. B. (1953). Phosphorylation coupled to electron transport in cell free extracts of Alcaligenes faecalis. J. biol. Chem. 205, 65 .

RACKER, E. (1965). Mechanisms in Bioenergetics. New York, London: Academic Press.

RAGLAND, T. E., KAWASAKI, T. \& LowensTeIN, J. M. (I966). Comparative aspects of some bacterial dehydrogenases and transhydrogenases. J. Bact. 91, 236.

Shockman, G. D., Kolb, J. C., Bakay, B., Conover, M. J.\& Toennies, G. (1963). Protoplast membrane of Streptococcus faecalis. J. Bact. $85, \mathrm{I} 68$.

SмITH, L. (1954). Bacterial cytochromes. Bact. Rev. 18, 106.

Umbreit, W. W., Burris, R. M. \& Stauffer, J. F. (1951). Manometric Techniques and Tissue Matabolism. Minneapolis: Burgess Pub. Co.

Whittensury, R. (1961). An investigation of the lactic acid bacteria. Ph.D. Thesis. University of Edinburgh. 
Whittenbury, R. (1964). Hydrogen peroxide formation and catalase activity in the lactic acid bacteria. J. gen. Microbiol. 35 , 13.

WhITtenbURY, R. (1965). The differentation of Streptococcus faecalis and Streptococcus faecium. J. gen. Microbiol. 38, 279.

YoNETAN, T. (1960). Studies on cytochrome oxidase. III. Improved preparation and some properties. J. biol. Chem. 236, 1680 . 